\title{
French Classicism in Jesuit Theater Poetics of the Eighteenth Century *
}

\author{
Nienke Tjoelker
}

A chapter on Jesuit theater poetics from the eighteenth century may seem odd in this collection about seventeenth-century baroque theater. However, despite the extensive existing body of secondary literature discussing the reception of French classicism in German vernacular literature, as well as the complicated relationship between French and German cultures, a Jesuit perspective on French classicism seems to be lacking in most accounts. ${ }^{1}$ In this chapter, I aim to remedy this and draw a more complete picture of the literary reception of French classicist drama in eighteenth-century German countries.

In the first part of this chapter ambivalent attitudes towards French culture in the German speaking areas will be discussed. Since Johann Christoph Gottsched played a central role in the reception of French culture both in the Protestant and Catholic areas, his works form a logical starting point. From there, I will proceed to discuss the political factors in this literary process. The third part of this chapter will focus on the Jesuit reception of French classicist poetics on the school stage in the German-speaking areas. This little known

* I am grateful to Jan Bloemendal, Nigel Smith and Florian Schaffenrath for their helpful comments and suggestions.

1 Cf. for example Werner Kraus, 'Der Weg der deutschen Aufklärung nach Frankreich', in Die französische Aufklärung im Spiegel der deutschen Literatur des 18. Jahrhunderts (Berlin Deutsche Akademie der Wissenschaften zu Berlin, 1963) Schriftenreihe der Arbeitsgruppe zur Geschichte der deutschen und französischen Aufklärung, 10, pp. CXxx-CLXxxviI. Reprint in Werner Kraus, Studien zur deutschen und französischen Aufklärung (Berlin, 1963) Neue Beiträge zur Literaturwissenschaft, 16, pp. 401-454. Cf. also Catherine Julliard, Gottsched et l'esthétique théâtrale française: La réception allemande des théories françaises (Bern, etc.: Peter Lang, 1998); Raymond Heitz, York-Gothart Mix, Jean Mondot and Nina Birkner (eds.), Gallophilie und Gallophobie in der Literatur und den Medien in Deutschland und in Italien im 18. Jahrhundert (Heidelberg: Universitätsverlag Winter, 2011); Reinhardt Meyer, 'Das französische Theater in Deutschland', in Matthias J. Pernerstorfer (ed.), Schriften zur Theater- und Kulturgeschichte des 18. Jahrhunderts (Vienna: Hollitzer, 2012), pp. 43-66 [first published in Gerhard Sauder and Jochen Schlobach (eds.), Aufklärungen: Frankreich und Deutschland im 18. Jahrhundert (Heidelberg: Carl Winter Universitätsverlag, 1985), pp. 145-165. 
movement within Jesuit school drama shows the continued development of this genre in the eighteenth century, and reveals a very different aesthetics than the baroque spectacle, for which Jesuit theater has become famous.

1

\section{French Culture in 18th century Germany: Between Gallophobia and Gallophilia}

The cultural relationship between the German and French cultures was a complicated and ambivalent one: on the one hand the German elite wanted to embrace French court culture, which was dominating Europe at the time; on the other it despised and feared France. The French themselves ridiculed the Germans with the stereotype of a simple, chubby figure with no good taste. ${ }^{2}$ Many learned collections of bon mots depicted the German as awkward and uncivilised, or at least as dishonorable. In the seventeenth century, the French used the expression 'vous me prenez pour un Allemand' when expressing the suspicion to be considered stupid. ${ }^{3}$

In Germany, French critique of its culture provoked an unsurprising reaction of outrage. Poets of the Silesian school, such as Benjamin Neukirch (1665-1729), Georg Philipp Harsdörffer (1607-1658) and Christian Friedrich Weichmann (1698-2770), called for support for the vernacular national literature, but, in contrast to the reaction in Italy, initially without much success. Nevertheless, gallophobia or even hatred of the French became common and deeply rooted

2 Cf. Heitz et al., Gallophilie und Gallophobie, p. xii; Erich Haase, 'Zur Frage, ob ein Deutscher ein "Bel Esprit" sein kann', Germanisch-Romanische Monatsschrift 9 (1959), 360-375, here p. 367. On the interesting phenomenon of imagology, cf. Joep Leerssen, 'Imagology: History and Method', in Manfred Beller and Joep Leerssen (eds.), Imagology: The Cultural Construction and Literary Representation of National Characters: A Critical Survey (Amsterdam and New York: Rodopi, 2007), pp. 17-32. Compare the imagological contribution on the perception of Holland versus Spain and England around 1640 in Marijke Meijer-Drees, Andere Landen, andere mensen: De beeldvorming van Holland versus Spanje en Engeland omstreeks 1650 (Den Haag: SDU, 1997) Nederlandse cultuur in Europese context: Monografiëen en studies, 6.

3 Heitz et al., Gallophilie und Gallophobie, p. xii. Similarly, stereotypes were central in ItaloFrench literary relationships. Provoked by denigrating remarks about the artificiality of Italian literature in Dominique Bouhours's De la manière de bien penser dans les ouvrages de l'esprit, several Italian replies appeared. For example, Gian Giuseppe Felice Orsi, Considerazioni sopra un famoso libro francese, intitolato 'La manière de bien penser' (Bologna: Costantino Pisarri, 1703). The defense against French criticism of Italian literature became central to the activity of the Accademia dell'Arcadia, an Italian literary academy founded in Rome in 1690. 
in the bourgeois intelligentsia (bürgerliche Intelligenz). ${ }^{4}$ Representatives of the early German nationalism were critical of the French fashion and frivolity, and journalistic literature frequently showed images of French phenomena, such as the extravagant wig fashion of the late Ancien régime. ${ }^{5}$

Despite this widespread gallophobia, an increasing number of French school books appeared in eighteenth-century Germany. ${ }^{6}$ In the final thirty years of this century, French became obligatory in most gymnasia in the German speaking areas, illustrative of the rising influence of French culture in these areas. Central to French lessons of this time was a command of a detailed regulated Komplimentierkunst ('art of complimenting'), which was to be achieved through learning by heart lists of phrases and expressions. ${ }^{7}$

The precondition for the success of French culture abroad was the blossoming of culture in France under Louis XIV (1638-1715). The king promoted art, literature and science financially, and surrounded himself by a large group of talented writers and artists, who were to become models for the whole of Europe in various genres, such as the influential painter Charles Le Brun (1619-169o), poets such as Nicolas Boileau (1636-1711) and dramatists such as Corneille, Racine and Molière. Political and diplomatic factors also played a large role in the French cultural hegemony in Europe from ca. 1650 onwards: politically France enjoyed a dominant position in Europe at the time. Also, France led the way in the development of efficient diplomacy and foreign ministry. ${ }^{8}$ During this period, a network of embassies and minor missions, link-

4 Werner Krauss, Studien zur deutschen und französischen Aufklärung (Berlin Akademie-Verlag, 1963), p. 401.

5 Reichardt Lüsebrink, 'Kauft schöne Bilder, Kupferstiche': Illustrierte Flugblätter und französisch-deutscher Kulturtransfer 16oo-1830 (Mainz: Hermann Schmidt, 1996), p. 80; Heitz et al., Gallophilie und Gallophobie, p. xi.

6 Heitz et al., Gallophilie und Gallophobie, p. xiii records 38 titles for the sixteenth century, compared to 173 for the seventeenth and at least 377 for the eighteenth century.

7 Heitz et al., Gallophilie und Gallophobie, p. xiii, and Gerhard Sauder, 'Die französische Sprache in Deutschland in der zweiten Hälfte des 18. Jahrhunderts', in Michel Grunwald and Jochen Schlobach (eds.), Méditations: Aspects des relations franco-allemands du XVIIe siècle à nos jours (Bern: Peter Lang, 1992) Contacts, Serie 2, Gallo-Germanica, 7, pp. 97-124, esp. p. 101.

8 William Young, International Politics and Warfare in the Age of Louis XIV and Peter the Great (Lincoln, NE: iUniverse, 2004), p. 39, who quotes in n. 6 Matthew S. Anderson, 'Diplomacy and International Relations', in id., Europe in the Eighteenth Century, 1713-1783, 2nd ed. (London: Longman, 1976), p. 201; John B. Wolf, The Emergence of the Great Powers, 1685-1715 (New York: Harper and Brothers, 1951), 5; Camille-Georges Picavet, 'La "carrière" diplomatique en France au temps de Louis XIV (1661-1715)', Revue d'histoire économique et sociale 11 (1923), 383-408, esp. p. 383 . 
ing most of the major European capitals and many of the smaller courts, was established, with France playing a principal role. ${ }^{9}$ Under Louis XIV it had the most widespread system of permanent embassies in Europe, and moreover, its ambassadors enjoyed a high reputation. ${ }^{10}$

Thus, Louis's court became a model for courts all over Europe. At the Prussian court, for example, French ceremonial was adopted in $1701 .{ }^{11}$ Frederick the Great (1712-1786) even hired French people for all of the culturally important positions in his court. In the 'Ritterakademien' (knight academies), schools for the German aristocracy, French was the main subject taught and the language through which all education was conducted. Also wealthy bourgeois families hired French teachers, sometimes deserters or refugees, with a dubious reputation, sometimes from members of Huguenot communities that had been in the country for longer. ${ }^{12}$

It is important to keep in mind in this complicated story that the German attitude towards French culture varied in different regions, among generations and social classes. ${ }^{13}$ As Raymond Heitz and his fellow-authors illustrate, rich merchants and specialized craftsmen in the northwestern German Hansestädte (Hanseatic towns), Franconia or Altbayern ('Old Bavaria') had their children trained in French, although this was highly unusual for their counterparts in the eastern Elbe region. ${ }^{14}$

Even in the opinion of one single person, the attitude towards France and its culture could differ with regard to particular aspects of it. Johann Christoph Gottsched (1700-1766) is a good example of this phenomenon: he could be described both as a Gallophile, who promoted French culture in Germany, and as a Gallophobe, who ridiculed and despised it.

The image of Gottsched in secondary literature is often dominated by the views of Gotthold Ephraim Lessing (1729-1781), who strongly criticized Gottsched in his 17. Literaturbrief. Although his intentions may not have been as serious as modern interpreters take them, his opinion on the value of Gottsched's imitation of the French cannot be misunderstood:

$9 \quad$ Young, International Politics and Warfare, p. 39.

10 Young, International Politics and Warfare, pp. 39-40.

11 Bernd Blaschke, 'Anleihen und Verachtung: Luise Gottscheds französischer Komödienimport als Arbeit an einem deutschen Theater', in Roman Luckscheiter and Marcel Krings (eds.), Deutsch-französische Literaturbeziehungen (Würzburg: Königshausen and Neumann, 2007), pp. 71-85, esp. p. 72 .

12 Ibid.

13 Raymond Heitz et al., Gallophilie und Gallophobie, p. xiv.

14 Ibid. 
Es wäre zu wünschen, das sich Herr Gottsched niemals mit dem Theater vermengt hätte. Seine vermeinten Verbesserungen betreten entweder entbehrliche Kleinigkeiten, oder sind wahre Verschlimmerungen. [...] Er verstand ein wenig Französisch und fing an zu übersetzen; er ermunterte alles, was reimen und Oui Monsieur verstehen konnte, gleichfalls zu übersetzen; er verfertigte [...] mit Kleister und Schere seinen 'Cato'; er ließ den 'Darius', die 'Austern' und den 'Witzling', die 'Banise' und den 'Hypocondristen', ohne Kleister und Schere machen; er legte seinen Fluch auf das extemporieren; er ließ den Harlekin feierlich vom Theater vertreiben, welches selbst die größte Harlekinade war, die jemals gespielt worden; kurz er wollte nicht sowohl unser altes Theater verbessern, als der Schöpfer eines ganz neuen sein. Und was für eines neuen? Eines Französierenden; ohne zu untersuchen, ob dieses französierende Theater der deutschen Denkungsart angemessen sei, oder nicht. ${ }^{15}$

(It would be desirable, that Mr. Gottsched had never become involved with the theater. His supposed corrections concern either dispensable trifles, or are true changes for the worse. [...] He understood a little French and started to translate; he likewise encouraged everyone who could rhyme or understand "Oui Monsieur" to translate. With scissors and glue ${ }^{16}$ he produced [...] his 'Cato'; he had 'Darius', the 'Oysters' and the 'Joker', the 'Banise' and the 'Hypochondriacs' produced without scissors and glue; he put a curse on improvisation; he had the harlequin festively removed from the theater, which in itself was the greatest buffoonery ever performed. In short, not so much did he want to improve our old theater, as want to be the founder of a brand new theater. And what kind of a new one? A Frenchifying one, without investigating whether this Frenchifying ${ }^{17}$ theater was suitable to the German way of thinking or not.)

15 Gotthold Ephraim Lessing, 17. Literaturbrief vom 16. Februar 1759, in Werke und Briefe in zwölf Bänden, ed. Wilfried Barner, vol. 4, Werke 1758-1659 (Frankfurt a. M.: Gunter E. Grimm, 1997), pp. 499f., esp. p. 499.

16 i.e. the concept of cut and paste.

17 On the term 'Frenchifying, cf. Heidi M. Schlipphacke, “"Vous appellés cela betrügen?”: Slippery French Morals and German Bourgeois Virtues in Selected Writings by G.E. Lessing', in Aminia M. Brueggeman and Peter Schulman (eds.), Rhine Crossings: France and Germany in Love and War (New York: State University of New York Press, 2005), pp. 35-66, esp. p. 40. 
In other words: according to Lessing it would have been better if Gottsched had never even tried his hand at theater, as he imitated the French theater in an unintelligent way that was unsuitable for the 'German way of thinking'. Lessing was not the only one to criticise Gottsched's slavish imitation of the French. In fact, Lessing's ruthless criticism on Gottsched's Cato was the conclusion of what has been called the 'Cato Controversy', a literary polemic that attacked not only Der sterbende Cato, but also, and especially, its author and his rationalistic poetics. ${ }^{18}$ At the time of its first appearance in 1732 , however, the play had a great success. It was celebrated as the first German tragedy and appeared in at least ten editions until $1757 \cdot{ }^{19}$

Lessing's remarks obviously only give a simplified version of Gottsched's reception of French classicism. Gottsched was no slavish imitator of its literature.

For example, in his moral weekly Die vernüfftigen Tadlerinnen, the fictive publisher 'Phyllis' refers to and denies the truth of French prejudices towards the Germans. Remarkably, however, Phyllis does not react by a general rejection of the French, but defends the Germans by stating that good taste ('der gute Geschmack') is at least as common among the Germans as among the French, who say they are superior in this respect:

Die Franzosen haben sich vor allen heutigen Völckern mit ihrem bon gout breit gemacht. Italien und Spanien ist von ihnen sehr verächtlich gehalten worden. [...] Uns Teutsche aber hat man gar mit denen Moscowitern, Finnen und Lappen in eine Classe gesetzet, und uns also mit Gewalt zu einem barbarischen Volcke machen wollen, welches sich keines guten Geschmackes anzumassen habe.

Dem ohngeachtet getraue ich mir die Ehre unserer Teutschen gegen alle unsre hochmüthige Nachbarn zu vertheidigen. Der gute Geschmack

18 Renate von Heydebrand, 'Johann Christoph Gottscheds Trauerspiel "Der sterbende Cato" und die Kritik: Analyse eines Kräftespiels', in Wolfdietrich Rasch, Hans Geulen and Klaus Haberkamm (eds.), Rezeption und Produktion zwischen 1570 und 1730: Festschrift für Günther Weydt zum 65. Geburtstag (Bern and München: Francke, 1972), pp. 553-569. Martin Brunkhorst, 'Die Cato-Kontroverse: Klassizistische Kritik an Addison, Deschamps und Gottsched', Literaturwissenschaftliches Jahrbuch 20 (1979), 71-87.

19 Cf. Christian Gottlob Köllner, 'Nachricht von den Schicksalen dieses sterbenden Cato in Frankreich und Deutschland', in Johann Christoph Gottsched, Ausgewählte Werke, vol. 2, ed. Joachim Birke (Berlin Walter de Gruyter, 1970), pp. 154-191 and pp. 168-170. This work mentions the number of 10 editions, but lists only nine in the 'Nachwort' by Joachim Birke, p. 455 . 
in freyen Künsten und anderen Dingen, so zum gemeinen Leben gehören, ist unter uns wo nicht häuffiger, doch gewiß eben so häuffig, als bey denen Frantzosen, die sich doch so klug düncken lassen, anzutreffen. ${ }^{20}$

(The French have made themselves famous among the peoples of today with their bon gout. They despise Italy and Spain. [...] Us, Germans, they consider to be of the same category as Moscovites, Finns and Lapps, and they forcibly want to take us for a barbarian people, which has no good taste.

Nevertheless I dare to defend the honor of our Germans against all our haughty neighbors. Good taste in liberal arts and other things belonging to the common life is among us, if not more frequently, then at least as frequently found as among the French, who consider themselves to be so smart.)

From this quotation, Gottsched's respect for the French as the leading literary trendsetters of his time is clear, but it is also evident that he does not follow them in all aspects. Gottsched, as well as his wife Luise Adelgunde, used French culture in their attempts to promote a 'national' German culture. They were mediators of French art theory, philosophy, religion and literature/theater in four ways: ${ }^{21}$ firstly, an important means of this cultural transfer was translation. Secondly, they followed and promoted French models in their poetics (Critische Dichtkunst $)^{22}$ and their weekly magazines. ${ }^{23}$ Thirdly, literary collections such as the Deutsche Schaubühne revealed a clear French influence, including both translations of French plays as original plays inspired by the French tradition. ${ }^{24}$

$20 \quad$ Johann Christoph Gottsched, Die vernüftigen Tadlerinnen, 2 vols. (Halle and Leipzig, 17251726), ed. Helga Brandes (Hildesheim, Zürich, New York: Olms, 1993), here vol. I, 1725, p. 34 .

21 Helga Brandes, 'Johann Christoph und Luise Adelgunde Victorie Gottsched und der deutsch-französische Aufklärungsdiskurs', in Jens Stüben (ed.), Ostpreußen-Westpreußen-Danzig: Eine historische Literaturlandschaft (Munich: R. Oldenbourg, 2007) Schriften des Bundesinstituts für Kultur und Geschichte des Deutschen im östlichen Europa, 30, pp. $237^{-258}$, esp. p. 238.

22 Cf. Catherine Julliard, Gottsched et l'esthétique théâtrale française: La réception allemande des théories françaises (Bern: Peter Lang, 1998) Convergences, 6; Roland Krebs, L'Idée du 'Théâtre National' dans L'Allemagne des Lumières: Théorie et Réalisations (Wiesbaden: Harrassowitz, 1985) Wolffenbütteler Forschungen, 28, pp. 30, 58, and 98.

23 Cf. Gabriele Ball, Moralische Küsse: Gottsched als Zeitschriftenherausgeber und literarischer Vermittler (Göttingen: Wallstein, 200o) Das achtzehnte Jahrhundert, Supplementa, 7.

24 On the Gottscheds' Deutsche Schaubühne, cf. Heide Hollmer, Anmut und Nutzen: Die Ori- 
Finally, the production of their own plays, following French models, was an expression of their cultural orientation.

In their translations, the Gottscheds aimed to contribute to the spread of the European Enlightenment. ${ }^{25}$ These were not translations in the modern sense of the word. Instead of an exact translation, loyal to the original, the text was often significantly altered to adapt it for its new German audience. The Gottscheds tackled a number of theoretical-scholarly works, such as Fénelon's Lettre à l'Académie, 1716 (translated by Luise Gottsched) and Batteux's Les beaux arts réduits à un même principe (1746).

The Gottscheds considered the theater of French classicism, characterised by its strict rules with regard to unities of time, place and action, a suitable model for the theater in Germany. ${ }^{26}$ In the preface to the second edition of the Critische Dichtkunst (1737) Gottsched praised Corneille and Racine, and considered them equal to Aristotle, Horace, Longinus, Julius Scaliger (14841558) and Nicolas Boileau (1636-1711). Pierre Corneille and Jean Racine, even though considered very different to each other during their life-time, are, in his poetics, representatives of the same 'regular' theater. ${ }^{27}$ In Die deutsche Schaubühne (1741-1745) he argued that, since there were no exemplary German 'regular' plays yet, and the ancient examples were too unknown for the average German spectator, the stage should be enriched with French plays. ${ }^{28}$ The aim,

ginaltrauerspiele in Gottsched's 'Deutscher Schaubühne' (Tübingen: NAAM, 1994) Theatron, 10.

25 Helga Brandes, 'Johann Christoph und Luise Adelgunde Victorie Gottsched', p. 239.

26 For a discussion of Corneille's influence on Gottsched, cf. Jean-Marie Valentin, 'Pierre Corneille en Allemagne (xvii-xixe s.): Une fortune paradoxale', Dix-septième siècle 2, 243 (2009), 307-320, esp. pp. 314-315.

27 To mention but one example, according to Gottsched in the plays of both the ancient classical authors as well as Corneille and Racine, at least one character remained on the stage in the transition from one scene to another. In the conclusion of his chapter on tragedy, Gottsched concludes (Schriften zur Literatur, ed. Steinmetz, p. 176): 'Und soviel mag auch von der Tragödie genug sein. Wer mehr wissen will, muß die hin und her angeführten Skribenten, sonderlich auch die Vorreden lesen, so Corneille und Racine vor ihre Stücke gesetzt haben.' On Gottsched's generalisation of the principles of Racine and Corneille, cf. Theile, Die Racine-Kritik bis 18oo, p. 93.

28 Blaschke, Luise Gottscheds französischer Komödienimport, p. 75 quotes Johann Christoph Gottsched, Die Deutsche Schaubühne, vol. 2, facsimile of the 1741-1744 print (Stuttgart: J.B. Metzlerische Verlagsbuchhandlung, 1972), p. 8: 'Daher habe man begonnen "unsere Bühnen mit den Stücken unserer Nachbarn zu bereichern", die sich "viel genauer nach den Regeln und Mustern der Alten gehalten, als unsere deutsche Dichter des vorigen Jahrhunderts"' 
however, was to become independent of the French, and to create a national German theater with the rules of classicist theater. Gottsched stated:

Vielleicht bringen wir es in kurzem so weit, dass wir gar keiner Behülfe unserer Nachbarn mehr brauchen, sondern von lauter eigenen Arbeiten unserer Landsleute diese Sammlung werden fortsetzen können. ${ }^{29}$

(Perhaps in a short while we will go such a long way, that we will not need any help from our neighbors anymore, but can continue this collection purely with the own works of our compatriots.)

As a translator of Bernard Le Bovier de Fontenelle's (1657-1757) Entretiens sur la pluralité des mondes (originally appeared 1686, Gottsched's translation appeared in 1726), Gottsched even earned the title 'der Teutschen Fontenelle' (the Fontenelle of the Germans). ${ }^{30}$ Through his translation of Fontenelle's Digression sur les Anciens et les Modernes (1688), Gottsched came into contact with the 'Querelle des Anciens et des Modernes', which was the main theme of the work. Gottsched's annotated translation of this work appeared in 1730 in Leipzig. ${ }^{31}$ In the context of the debate, Fontenelle's work was seen as the manifest for 'anti-classicist modernists.' ${ }^{32}$ Gottsched, on the other hand, was a strong admirer of the classics, both in their original Greek and Roman form and in the form of French classicism. Nevertheless he was influenced also by Fontenelle's modernism, in the sense that he believed in the cultural possibilities of his own time. Gottsched combined elements from both the Modernes and the Anciens in this cultural transformation. ${ }^{33}$ On the one hand he admired and imitated the Anciens (Boileau, La Fontaine, Racine, La Bruyère), on the other the Modernes (Perrault, Fontenelle, Saint-Évremond), filtering out from each what seemed important in a particular situation. ${ }^{34}$

29 Gottsched, Die Deutsche Schaubühne, vol. 2, p. 42.

3o Ibid., p. 243; Günther Gawlick, 'Gottsched als Vermittler der französicehn Aufklärung', in W. Martens, Zentren der Aufklärung III: Leipzig: Aufklärung und Bürgerlichkeit (Heidelberg: Lambert Schneider, 1990) Wolffenbütteler Studien zur Aufklärung, 17, pp. 179-204, esp. p. 182.

Bernhard von Fontenelle, Abhandlung der Frage, vom Vorzuge der Alten oder Neuern im Absehen aufKünste und Wissenschaften (Leipzig: Breitkopf, 1730), pp. 256-294.

32 Ibid., p. 243, referring to Werner Krauss, Aufklärung III, Chapter: 'Der Weg der deutschen Aufklärung nach Frankreich während des 18. Jahrhunderts', pp. 100-117, here p. 116.

33 Brandes, Johann Christoph \& Luise Adelgunde Victorie Gottsched, p. 244.

34 Ibid. 
Gottsched, therefore, pleaded with nuance for the adoption of French models, if he considered them suitable for the advancement of German literature in the tradition of the ancient classics. In poetry, on the other hand, he considered French lyrical poets of less value than their German counterparts, since the French language, in his view, was less suitable for expressing the diversity of ancient metrics, than the German language. ${ }^{35}$

Luise Gottsched was also a critical follower of French culture. Despite numerous translations of French works, her works reveal a strong resentment against the French. Her comedy Die Hausfranzösin, for example, even though perfectly following the French classicist rules of poetics, has a number of gallophobe themes and motives. ${ }^{36}$ To mention just one example of her attitude in this work, French cuisine is ridiculed and abused. The sick servant 'Sotenville' ('the fool in town') is served spiced pigeon manure, which pleases his French taste, but causes colic afterwards. Apart from that, 'Luischen', one of the daughters of the family, criticizes the French cuisine for being unnatural, wrong and unhygienic. Also the story itself is obviously discussing the two extreme attitudes towards France: a German family is divided into a gallophobe camp and a gallophile camp when the son, with the speaking name 'Franz', proposes to join his French teacher on a visit to France. He is the gallophile in the family, together with his little sister 'Hannchen'. His uncle 'Wahrmund' ('Speaker of the truth') and patriotic sister 'Luischen' (sharing her name with the author, Luise Gottsched) are strongly against this plan, since the French teacher, the Hausfranzösin, along with her servant Sotenville (who turns out to be her father and a criminal on a wanted poster), aim to rob the family. Overall, an anti-French sentiment dominates the play, while at the same time the rules of the French classicism are followed in its form.

The Gottsched's rationalist French-inspired poetics should be seen in the context of Enlightenment (Aufklärung) ideas that developed in Protestant Germany. A rationalist tendency, which was later called 'Neology', flourished between about 1740 and the end of the century. ${ }^{37}$ Reason was the central concept for the Neologians, and even though they did not reject revelation or the divinity of Christ, they viewed everything that did not conform to reason with suspicion. French classicist poetics, which gave strict regulations with

35 Meier, Plus Ultra! Johann Christoph Gottscheds gallophobe Gallophilie, pp. 195-205.

36 This discussion of Luise Gottsched's Die Hausfranzösin is based on Blaschke.

37 Joachim Whaley, 'Protestant, Catholic, and Jewish Aufklärung', in id., Germany and the Holy Roman Empire, vol. II: The peace of Westphalia to the Dissolution of the Reich 1648 1806 (Oxford: Oxford University Press, 2012), pp. 470-484, esp. p. 471. 
regard to the unities of place, time and action, and did away with unnecessary ornamentation, fitted well with these rationalistic ideas.

In the previous paragraph, I have elucidated Gottsched's French-inspired poetics, inspired by Enlightenment ideas. In Catholic German-speaking areas, the Enlightenment had a different impact. ${ }^{38}$ Traditional, Counter-reformation Catholicism continued to play an important role in its society, along with its characteristic traditions, such as the Marian cult. The cult of the Eucharist, which celebrated the most important distinction between Catholicism and Protestantism, became increasingly popular in the eighteenth century. ${ }^{39}$ Therefore, it may seem surprising that eighteenth-century Jesuits took the Protestant Gottsched as their model and imitated his French-inspired classicist poetics.

To explain this, two developments within Catholic Europe should be considered.$^{40}$ Firstly, a more simple, austere piety was promoted by the Italian reformer Ludovico Antonio Muratori $\left(1_{672-1750)}\right.$. As we will see later in this chapter, Muratori proved to be extremely influential in the German-speaking areas.

Secondly, Protestant scholars and writers, such as Gottsched, increasingly presented themselves as superior to their Catholic counterparts. Self-criticism among the Catholics became more common, and the main initiatives for reform came from educated laymen, of Catholic rulers and certain religious

38 On the Catholic Enlightenment in the German speaking area (Aufklärung), cf. Bernhard Plongeron, 'Was ist Katholische Aufklärung?', in Elisabeth Kovács (ed.), Katholische Aufklärung und Josephinismus (Vienna: Verlag für Geschichte und Politik, 1979), pp. 1156 .

39 Whaley, 'Protestant, Catholic, and Jewish Aufklärung', p. 477.

40 Ibid. Whaley also mentions two other developments: Jansenism and the educational reforms surrounding Christian Freiherr von Wolff. Jansenism promoted a more simple, austere, unadorned piety. Of course, this cannot have been a direct factor in the case of the Jesuits, as they were the opponents of the Jansenists. The reform of Catholic universities that Friedrich Karl von Schönbrunn (1674-1746) had begun at Würzburg in the 1720 s became more widely accepted by Catholic scholars from the 1740 . They enthusiastically embraced the ideas with regard to higher education of Christian Freiherr von Wolff (16791754), who argued for a complete and self-sufficient educational system instead of the existing Neo-Scholastic Jesuit teaching. 
orders (such as the Benedictines). The Jesuits were the main targets of these reformers, who considered them conservative and encouraging superstition and excess. ${ }^{41}$ From the late seventeenth century, they were increasingly under attack for the lack of functionality of their theater. Already during the reign of Leopold I (1640-1705), the Austrian nobility asked the Jesuits to focus their education more on topics of practical use for the future professional life of their students, but at this time the Jesuits still enjoyed the full support of Leopold. When the nobility's request was ignored, it founded its own schools, exclusively for children of the nobility: the Ritterakademien. ${ }^{42}$ The first of these in Austria was founded in 1682 in Vienna. The curriculum in these schools included law, history, geography, modern languages (French, Italian and Spanish), mathematics, physics, religion and sports, and it became a model for the curricula in Austrian gymnasia.

It was also in the interest of the government to have a useful and disciplined youth to their disposal. A learned one, such as that educated by the Jesuits, which moreover began to include more and more children of lower social ranks, was much less so. Therefore, as early as 1668 , in spite of resistance from the religious orders, the government actively promoted a stricter (social) selection for entry to the gymnasium. ${ }^{43}$ Almost sixty years later, in 1734 , the imperial government in Vienna warned the Jesuits in Graz, that not just any untalented boy of low social rank be admitted, but that he should serve the common good in a more suitable manner:

... dass nicht jeder von gemeinem Stand herkommende und nicht wohl talentirte Knab ad studia zugelassen, sondern vielmehr zu seinem eigenen und des Publici besserem Nutzem zu was anderem nach seiner Fähigkeit angewendet werde. ${ }^{44}$

41 Whaley, 'Protestant, Catholic, and Jewish Aufklärung', p. 479.

42 Gerald Grimm, Die Schulreform Maria Theresias 1747-1775: Das österreichische Gymnasium zwischen Standesschule und allgemeinbildender Lehranstalt im Spannungsfeld von Ordensschulwesen, theresianischem Reformabsolutismus und Aufklärungspädagogik (Frankfurt am Main: Peter Lang, 1987), p. 257.

43 Ibid., pp. 258-259.

44 Resolution of the government dated 26. May, 1734. It is quoted in Franz von Krones, Geschichte der Karl Franzens-Universität in Graz: Festgabe zur Feier ihres dreihundertjährigen Bestandes (Graz: Verlag der Karl-Franzens-Universität, 1886), p. 6o; and again by Grimm, Die Schulreform Maria-Theresias 1747-1775, p. 259. 
(... that not every low-born and not very talented boy should be admitted to study, but rather that he should be employed, for his own good and for the common good, for something else, suited to his capability.)

For the Jesuits however, government reforms did not materialize until 1735, when the first attempts of a reform of the gymnasia were made in the Studienordnung of Emperor Charles vi $\left(1685^{-1740)}\right.$. These were still very mild measures, since the Jesuits had already shown goodwill by their introduction of a chair of universal history at the university of Vienna in $1729 .{ }^{45}$

Defeats in the war of the Austrian Succession (1740-1744) and the Seven Years' War (1756-1763) in Catholic Austria created a feeling of inferiority in comparison with Protestant Prussia and were an incentive to reform in Austria. Maria Theresa (1717-1780), who had come to power in 1740, drastically reformed the state system. The administration of the state was reformed, dividing its tasks over a state chancellery, a state council and the Directorium in publicis et cameralibus, charged with the management of internal affairs. ${ }^{46}$ Other reforms included the introduction of district commissions, the creation of a general land register and the establishment of a military academy in Vienna. ${ }^{47}$ Further, she appointed Wenzel Anton von Kaunitz (1711-1794), an aristocrat with reformist and Enlightenment ideas, as her new state chancellor. ${ }^{48}$ Educational reforms, which were aimed at creating patriotic citizens who were useful to the state, brought important changes to the school curriculum, introducing new, enlightened ideas to the Austrian pupils, new subjects (such as French and History) and, by abolishing Jesuit censorship, making available previously banned books. ${ }^{49}$ Frederick the Great served as an example in these reforms, ${ }^{50}$ in the sense that Maria Theresa aimed for the Habsburg Empire to keep up with Prussia's reforms. Although Maria Theresa was deeply religious and did not follow a complete theoretical program of Enlightenment ideas, she and

45 Grimm, Die Schulreform Maria-Theresias 1747-1775, p. 262.

46 For a short summary of Maria Theresa's reforms, cf. Balács Trencsényi and Michal Kopeček (eds), Discourses of Collective Identity in Central and Southeast Europe (1770-1945): Texts and Commentaries, vol. 1: Late Enlightenment: Emergence of the Modern 'National Idea' (Budapest: Central European University Press, 2006), p. 128. Cf. also the standard work on Maria Theresa: Alfred A. Ritter von Arneth, Geschichte Maria Theresias, 10 vols. (Vienna: Wilhelm Braumüller, 1863-1879).

47 Ibid.

48 Ibid.

49 Ibid.

$5^{\circ} \quad$ Ibid., p. $5^{8}$. 
her advisers were strongly influenced by the ideas of the Enlightened Absolutism (Aufgeklärter Absolutismus). ${ }^{51}$

Rationality, uniformity, utility and functionality were central concepts in both her state reforms and in her educational policy. The prominent role in Jesuit education of school theater, characterized by its spectacle and entertainment, which the Jesuits had developed since the early existence of the order, did not fit this idea of a general education. The emphasis in Jesuit education on learning Latin and performing in spectacular school drama took away precious time from the cultivation of other skills which could be useful for the state, such as language skills (French, German), historical and geographical knowledge, and other qualities such as patriotism. An emphasis on the moral function of theater and a strict application of the rules of the French classicism, on the other hand, corresponded better to it, and became an (unsuccessful) attempt of some influential Jesuits to defend and continue the practice of school theater. The fact that Maria Theresa was strongly influenced by French court culture must have been a factor too in their modifications to Jesuit school theater.

In 1759, Maria Theresa would appoint Giovanni Battista de Gaspari, a former student of the previously mentioned Italian theologian and historian Lodovico Antonio Muratori, ${ }^{52}$ as director scholarum humaniorum. In the following years he implemented a systematic reform in the educational system in Austria. ${ }^{53}$ In the 1760 s, this meant a complete prohibition of the use of theater in the schools. ${ }^{54}$ In 1764 he presented his Instructio pro scholis humanioribus, in which he emphasized the general educational function of the gymnasium. ${ }^{55}$ Education should serve the common good. His curriculum officially replaced the

$51 \quad$ Ibid.

52 On Muratori and his conception of 'enlightened christianity', cf. Grimm, Die Schulreform Maria Theresias $1747^{-1775}$, pp. $195^{-205}$.

53 Ibid., pp. 298-318.

54 Ellen Hastaba, “Jesuitenspiele” in Innsbruck (1562-1773)', in Kurt Drexel and Monika Fink (eds.), Musikgeschichte Tirols, vol. II: Von der Frühen Neuzeit bis zum Ende des 19. Jahrhunderts (Innsbruck: Universitätsverlag Wagner, 2004) Schlern-Schriften, 322, pp. 375-413; Stefan Tilg, 'Die Entwicklung des Jesuitendramas vom 16. bis zum 18. Jahrhundert: Eine Fallstudie am Beispiel Innsbruck', in Reinhold Glei and Robert Seidel (eds.), Das lateinische Drama der Frühen Neuzeit: Exemplarische Einsichten in Praxis und Theorie (Tübingen: Max Niemeyer, 2008), pp. 183-200.

55 The Latin text and a German translation of the Instructio pro Scholis humanioribus is published in Helmut Engelbrecht, Geschichte des österreichischen Bildungswesens: Erziehung und Unterricht aufdem Boden Österreichs, 3 vols. (Vienna: Österreichischer Bundesverlag, 1984), pp. 467-482. 
Ratio studiorum of the Jesuits in all Austrian gymnasia and introduced new subjects such as Greek, German, history and geography.

\section{Theory, Politics and Aesthetics: Jesuit Classicist Poetics in the German Speaking Areas (Friz, Neumayr, Weitenauer)}

From the point of view of government reform, therefore, the attempt of the Jesuits to save their school drama using French classicist rules is understandable. Also, French classicism as such was not 'new' for the Jesuits in the eighteenth century. Pierre Corneille (1606-1684), one of the most important representatives of this movement, was closely linked to the Jesuit tradition of theater, even in his lifetime. ${ }^{56}$ Corneille himself, being a Jesuit alumnus, was strongly influenced by contemporary Jesuit poetics in his theater practice. ${ }^{57} \mathrm{He}$ was a pupil of 'La Flèche' (Rouen) and Pont-à-Mousson, where he enjoyed an education from the best Jesuit teachers of his time. He was in contact with famous Jesuits such as Nicolas Caussin and Louis Cellot, and, up to the end of his life, with Claude Delidel, Charles De la Rue and Gabriel Le Jay. ${ }^{58}$ Corneille's interpretation of the tragedy in which the sublime was central, rather than a morality based on verisimilitude, was very similar to the Jesuit theater. It relied on an 'esthetic catharsis', meaning, a catharsis based on admiration and pathos. ${ }^{59}$

Corneille himself became exemplary for the Jesuits in the late seventeenth century, when the French Jesuit Joseph Jouvancy included Corneille in a list of his most important models, next to Aristotle, Horace and Abbé H. D' Aubignac, in what became a standard guide and method for classical studies at Jesuit colleges all over Europe, De ratione discendiet docendi. ${ }^{60}$ At first sight, therefore,

56 Valentin, 'La diffusion de Corneille en Allemagne', pp. 171-199. Cf. also Jean-Marie Valentin (ed.), Pierre Corneille et l'Allemagne: L'oeuvre dramatique de Pierre Corneille dans le monde germanique (XVIIe-XIXe siècles) (Paris: Desjonquères, 2007); id., 'Pierre Corneille en Allemagne (xvii-xixe s.): Une fortune paradoxale', Dix-septième siècle 2, 243 (2009), 307-320; André Stegmann, L'Hérö̈sme cornélien, genèse et signification, part II: L'Europe intellectuelle et le théâtre (1580-1650): Signification de l'hérö̈sme cornélien (Paris: Armand Colin, 1968); Marc Fumaroli, Héros et orateurs: Rhétorique et dramaturgie cornéliennes (Genève: Droz, $\left.1996^{2}\left[1990^{1}\right]\right)$, pp. $63^{-208 .}$

Cf. Anne-Élisabeth Spica, 'Corneille et les poétiques jésuites: Une dramaturgie comparée', in Myriam Dufour-Maitre (ed.), Pratiques de Corneille (Rouen and Du Havre: Presses Universitaires, 2012), pp. 371-385.

$5^{8}$ Ibid., p. 372.

59 Ibid., p. 379 .

6o Joseph Juventius, De ratione discendi et docendi (Paris: Fratres Barbou, 1725), p. 74. Cf. also 
this seems not at all unusual: Corneille, considering his relationship to the Jesuits, was an acceptable model for the order. At a closer look, however, imitation of Corneille signals a completely new Jesuit poetics. Although the traditional baroque appreciation given to music, dance and elaborate stage sets is still present in his poetics, Jouvancy considered respect for the three unities important. This meant that the action should be complete and logical, with one action proceeding from the other and consisting of a beginning, middle and end. On these grounds Seneca's tragedies were rejected. ${ }^{61}$ The same rule counted for space and time, in which no incredible jumps should occur. Corneille had discussed these rules in his Trois discours sur le poème dramatique (1660), which he published as a preface to the three volumes of his collected works, and in the Examens, published in the same collection of his works. The Discours took the form of a didactic exposition and commentary on Aristotle. In the Examens, Corneille analyzed his plays critically testing them on the rules set in the Discours, revealing that even he himself in practice failed to follow them consistently. ${ }^{62}$ These rules, which therefore should be considered general rules of the genre of drama in the tradition of French classicism, rather than rules which Corneille respected himself in his plays, were to become the main aspect of imitation in a completely new Jesuit theater poetics in the eighteenth century.

In the eighteenth century, Corneille was often mentioned alongside his lifelong rival Jean Racine (1639-1699), who may not seem like a logical choice as a model for the Jesuits. Especially because of his treatment of love in his plays, the French Jesuit Father Charles Porée $\left(1675^{-1741}\right)$ had criticized Racine for the lack of morals in his plays in a speech delivered in the Collège Louis-leGrand in $1733 \cdot{ }^{63}$ However, in a rationalist vein of poetics among the Jesuits in the German speaking areas, of which the Epistola de Tragaediis by the Austrian Jesuit Andreas Friz (1711-1790) is an early example, Jean Racine, Pierre Corneille (16o6-1684), Molière, Pietro Metastasio and Granelli all feature as models, with Jean Racine taking a central position. ${ }^{64}$ For the German Jesuits Franz Neumayr

Rudolf Rieks, Drei lateinische Tragiker des Grand Siècle (München: Verlag der Bayerischen Akademie der Wissenschaften, 1989), pp. 12-13.

61 Juventius, De ratione discendi et docendi, p. 74.

62 On Corneille's Examens, cf. David Maskell, 'Corneille's Examens Examined: The Case of Horace', French Studies 51 (1997), 267-280.

63 Charles Porée, Theatrum sitne vel esse possit schola informandis moribus idonea, ed. with French transl. (Paris: Joannes Baptista Coignard, 1733), pp. 30-31.

64 Cf. the edition and extensive introduction in Nienke Tjoelker (ed.), Andreas Friz's Letter on Tragedies (ca. 1741-1744): An Eighteenth-century Contribution to Theatre poetics (Leiden 
(1697-1775) and Ignaz Weitenauer (1709-1783) both Corneille and Racine were also very important. ${ }^{65}$

As discussed above, the Jesuits had different problems to address in the eighteenth century than their fellow members a century earlier. In the sixteenth century, they had taken up the theater in a Counter-Reformation context. In the sixteenth and seventeenth centuries, their theater became an extremely successful, socially important phenomenon all over Europe. ${ }^{66}$ School pupils and university students regularly performed comedies, tragedies and other types of plays, drawing a large percentage of a city's inhabitants to the schools, either as participants or spectators. Spectacle and entertainment were the famous characteristics of this theater: things that, by the eighteenth century according to Andreas Friz, on the other hand, were precisely better left out of a play: all types of ornaments outside of the action of a play should be condemned, and the focus should be fully on the action of a play. Friz's ideas on theater are included in a manuscript, now held at the university library of Graz. This manuscript is a collection of theoretical works on theater and examples of good plays, written or translated by Friz between 1741 and 1744. The first part of the manuscript (f. $\left.1^{\mathrm{r}}-74^{\mathrm{v}}\right)$ is devoted to an analysis of eleven tragedies by Racine: La Thebayde ou Les Frères Ennemis, Alexandre Le Grand, Andromaque, Britannicus, Bérénice, Bajazet, Mithridate, Iphigénie, Phèdre, Esther and Athalie. ${ }^{67}$ In it, Friz presented the plays as models for Jesuit playwrights. Qualities that he admired particularly are the use of passions to evoke hate of vice and love of virtue and the construction of a principal action according to the unities of time, place and action. The way in which characters, events or other aspects of a play contribute to its moral function is also discussed.

and New York: Brill, 2014), Drama and Theatre in Early Modern Europe, 4. On Weitenauer, cf. Edith Kellner, Ignaz Weitenauers Ars Poetica und Tragoediae Autumnales (unpublished doctoral thesis, University of Innsbruck, 1958).

65 On Neumayr's poetics, cf. Hermann Wiegand, 'Späte Jesuitenpoetik: Die Idea Poeseos von Franz Neumayr sJ (1697-1765)', in Beate Hintzen and Roswitha Simons (eds.), Norm und Poesie: Zur expliziten und impliziten Poetik in der lateinischen Literatur der Frühen Neuzeit (Berlin and Boston: De Gruyter, 2013) Frühe Neuzeit, 178, pp. 111-124.

66 For a short introduction to Jesuit drama with bibliography, cf. Ruprecht Wimmer's lemma 'Jesuitendrama', in Georg Braungart a.o. (eds), Reallexikon der deutschen Literaturwissenschaft, 2 (Berlin, etc.: Walter de Gruyter, 2007), pp. 196-199. On the first two centuries of Jesuit theater, cf. Jean-Marie Valentin, Le théatre des Jésuites dans les pays de langue allemande (1554-1680): Salut des âmes et ordre des cités, 3 vols. (Bern-Frankfurt-Las Vegas: Peter Lang, 1978).

67 Cf. the short introduction to these analyses and a complete Latin edition in Tjoelker, Andreas Friz's Letter on Tragedies, pp. 173-282. 
Folios $76 \mathrm{r}$ to $166 \mathrm{v}$ contain a section entitled Opera Metastasii. In this section are the Latin translations of three librettos by Pietro Metastasio (1698-1782): Themistocles, Titus and Cyrus. ${ }^{68}$ The third section is entitled Opera Granellii and contains Latin translations of two plays by Giovanni Granelli (1703-1770): Sedecias $\left(169^{\mathrm{r}}-188^{\mathrm{r}}\right)$ and Manasses $\left(188^{\mathrm{v}}-212^{\mathrm{r}}\right)$. Folios $212^{\mathrm{v}}-220^{\mathrm{r}}$ contain Friz's translation of Giuseppe riconosciuto (1733) by Pietro Metastasio, with the title Joseph, a fratribus suis adoratus et agnitus. Giuseppe riconosciuto is an oratorio libretto (religious drama) that Metastasio wrote while at the Habsburg court in Vienna. The inclusion of these plays is illustrative of Friz's proximity to the court. His father, Adrian von Friz, was court harbinger (Hoffourier) of Archduke Charles, who had been proclaimed King Charles III in $1705 \cdot{ }^{69}$ Andreas Karl Josef von Friz (Andreas Friz) was born in Barcelona, at the time of Charles's court. In the following years, the Friz family returned to Vienna, where Andreas's brother Edmund, who also became a Jesuit, was born in 1714. His sister Elisabeth von Friz (born 1718) was as close to the government as a woman could be in those days: she was a personal assistant and confidante of Maria Theresa. ${ }^{70}$

The final part of the manuscript $\left(222^{\mathrm{r}}-315^{\mathrm{v}}\right)$ has the title Opera R.P. Andreae Friz e S.J. and contains Friz's Epistola de Tragaediis as well as four plays by Friz: Alexis, Salomon, Psychis and Codrus. His letter on tragedies is a theater poetics, which urges Jesuit playwrights to apply the rules of French classicism very strictly: the three unities should be respected and no distracting and immoral interludes should be included. This emphasis on rules and regularity strongly resembles Gottsched's interpretation of the French classicism. In fact, it is likely that Friz was directly inspired by Gottsched's Versuch einer Critischen Dichtkunst. ${ }^{71}$ In a passage concerning the three unities, for example, Friz's words are an almost literal translation of Gottsched's words. ${ }^{72}$ Friz's poetics could be criticized in the same way as Gottsched's was: it could result in boring plays. Friz discussed this possible response already in his poetics, stating that

68 Mareike Einfalt, Ludwig Fladerer and Ulrike Syrou, 'Beschreibung der Handschrift 938', p. 4, in Die Antikerezeption an der Grazer Universität, http://gams.uni-graz.at/archive/get/ o:arj-07A-14/sdef:TEI/get.

69 Louis von Frizberg, 'Andreas von Friz: Der letzte Wiener Jesuitendramatiker', Alemania 5 (1931), 43-101, esp. p. 43.

70 Louis von Frizberg, Elisabeth von Friz: Ein Liebling der Kaiserin Maria Theresia (Vienna: privately printed, 1954).

71 Cf. Bernhard Weybora, 'Die Epistula de tragoediis von Andreas Friz' (unpublished dissertation University of Graz, 1940), pp. 95-99.

72 Compare Gottsched, Versuch einer kritischen Dichtkunst (Leipzig: Breitkopf, 1730), p. 575 and Friz, Epistola de Tragaediis, fol. 227v. 
if the actors acted well, followed the rules of rhetorics and the play were easily understandable, it would still be entertaining for the audience.

Around the same time, in 1741 in Augsburg, another Jesuit, Anton Claus (1691-1654) published a collection of tragedies. ${ }^{73}$ They appeared in a second edition in 1753 in Augsburg-Würzburg. Translations were published in Polish (Vilnae 1751) and German (Augsburg 1776). The theater exercises that he wrote for school use were published in Ingolstadt, Augsburg and Innsbruck in $1750 .{ }^{74}$ Most of his plays were performed in Innsbruck, where he worked between 1730 and 1735. In the introduction to the edition of his tragedies, Corneille is put on the same level as the ancient sources, and called the 'prince of the tragic poets', following the example of the French Jesuit Charles de la Rue $\left(1643^{-1725}\right) \cdot{ }^{75} \mathrm{De}$

73 On Anton Claus, cf. Valentin, 'La diffusion de Corneille en Allemagne au XvııIe siècle', p. 179, who refers to the most important works on Claus in general: Sommervogel, Bibliothèque de la compagnie de Jésus (Brussels: Oscar Schepens; Paris: Alphonse Picard, 1890-1932), vol. II (1891), pp. 1204-1205; Herbert Gerl, Catalogus generalis Provinciae Germaniae Superioris et Bavariae Societatis Jesu 1556-1773 (Munich: unpublished catalogue, 1968), p. 64; Nikolaus Scheid, Das Lateinische Jesuitendrama im Deutschen Sprachgebiet (Freiburg: Herder, 1930), p. 26; Willi Flemming, Geschichte des Jesuitentheaters in den Ländern Deutscher Zunge (Berlin Gesellschaft für Theaterwissenschaft, 1923) Schriften der Gesellschaft für Theaterwissenschaft, 32, p. 14; Stefan Tilg, 'Theater', in Martin Korenjak, Florian Schaffenrath, Lav Subaric and Karlheinz Töchterle (eds.), Tyrolis Latina: Geschichte der lateinischen Literatur in Tirol, vol. 2. Von der Gründung der Universität Innsbruck bis heute (Vienna, Cologne and Weimar: Böhlau, 2012), pp. 661-70o, esp. pp. 672-675. On his life, cf. Ms. XVII 2/52; VI 3; XI 26/2; VI 18 in the archives of the Jesuits, Ignatius-Haus, Munich. Valentin's information on Claus is based further on the information found in the archives held at the Hauptstaatsarchiv of Munich: Jesuitica, Catalogi personarum.

74 Anton Claus, Exercitationes theatrales authore P. Antonio Claus s.J. Sacerdote (IngolstadtAugsburg: F.X. Crätz and Th. Summer, 1750) and Exercitationes theatrales a S.J. magistris inferiorum classium dirigente P. Antonio Claus, eiusdem Societatis in Episcopali et Academico Gymnasio dilingano exhibitae (Augsburg and Innsbruck: J. Wolff, 1755). Cf. the forthcoming edition of his Publius Cornelius Scipio sui Victor: Simon Wirthensohn (ed.), Anton Claus sJ: Publius Cornelius Scipio sui victor (1741) ed., intr., transl. and notes (Freiburg in Breisgau: Rombach, in print). Unfortunately I was unable to access this edition during the preparation of this article.

75 Claus, 'Praefatio ad lectorem', p. 4: 'Antiquiorum enim vestigia, non tamen regulas, deserere ausus Petrum Cornelium, quem Tragicorum Principem Ruaeus noster, assentiente litterato orbe, appellat, sequi conatus sum, etsi non passibus aequis.' ('For I, daring to abandon the traces of the older poets, but not their rules, tried to follow Pierre Corneille, but not with equal steps'). On Charles de la Rue, cf. Valentin, 'La diffusion de Corneille en Allemagne au XviıIe siècle', p. 180, n. 33; Sommervogel, Bibliothèque de la compagnie de Jésus, vol. viI (1896), pp. 290-307. 
la Rue had a successful career as a professor of rhetoric at the Louis-le-Grand college, and as a preacher. He died in Paris at 1725. Two of De la Rue's plays, Cyrus and Lysimachus were published in Ingolstadt in 1722. They served as important mediators of French literature in Germany. Like Corneille, Claus introduced his plays in this edition with a short commentary on the unities of action, time and place in his plays, the characters of the heroes, intended as practical tips for future playwrights:

Subiungo singulis Tragoediis quasdam observationes, in eorum potissimum gratiam, quos idem, qui me diu exercuit, Theatralis labor exspectat. $^{76}$

(I attach some observations to all the tragedies separately, to the greatest regard of those, whom the same labor of theater awaits, which trained me for a long time.)

Like Friz, there is a strong emphasis on the rules for dramatic structure, which in their view guarantee the moral effectiveness. It should be noted that the editions of plays by Claus as well as Friz enjoyed a great success and therefore represent by no means a marginal phenomenon among the German Jesuits.

Ten years later, in 1751, the Bavarian Franz Neumayr (1697-1775), also mentions the French classicists prominently, including Racine along with Pierre and Thomas Corneille, the French Jesuits De la Rue and Porée, ${ }^{77}$ the Italian Metastasio, Gottsched as the German vernacular model, and Anton Claus, for the Latin, in his list of contemporary models for the genre of tragedy:

Princeps habetur Cornelius senior et junior, quibus proxime accedit Racine, Ruaeus, uti et Poyre Galli, Metastasius Italus, Gottsched et Clausius, ille germanus, hic latinus. ${ }^{78}$

(Corneille senior is considered the prince, as well as Corneille junior. They are followed closely by the French Racine, De la Rue and Porée, the Italian Metastasio, and Gottsched and Claus, the former German, the latter Latin.)

76 Claus, 'Praefatio ad lectorem', p. 5 .

77 On Porée, cf. Rieks, Drei lateinische Tragiker des Grand Siècle, pp. 43-57.

78 Franz Neumayr, Idea poeseos, p. 173. Cf. Frank Pohle, Glaube und Beredsamkeit: Katholisches Schultheater in Jülich-Berg, Ravenstein und Aachen (1601-1817) (Münster: Rhema, 2010), p. 301, n. 334; Valentin, 'La diffusion de Corneille en Allemagne au Xvıı Ie siècle', p. 187. 
Neumayr was a contemporary of Friz and his first play appeared on stage in 1731 at Munich. ${ }^{79}$ His Idea poeseos is a handbook for those who had to discuss poetics with their students. ${ }^{80}$ It illustrates the same turn to classicism as Claus and Friz. ${ }^{81}$ Similar to Friz, Neumayr emphasizes the moral usefulness of literature:

Finem porro quia diximus in eo consistere, ut delectando prosis (omnis enim ars ex sua essentia subordinatur Politiae, cujus est bono publico invigilare, atque ne quis in noxiis aut inutilibus laboribus occupetur, cavere .... $)^{82}$

(Further, we have indicated that the end [of drama] consists in this: the usefulness through pleasing (for each art is in essence subordinated to the state, whose duty it is to guard the common good, and to be careful, that one is not occupied with harmful or useless things ...))

Also the connection between education, the art of theater and creating good citizens, who contribute to the common good of a state becomes clear in this quotation. Respect for the structural rules of the French classicism, which meant the play contained as little distraction from its moral message as possible, is the condition for this effect. However, in order to please the audience's taste for spectacle, Neumayr combined regular classical structure with baroque interludes in his plays. ${ }^{83}$

Another six years later, in 1757, Ignaz Weitenauer published his commentary on Horace's Ars poetica. ${ }^{84}$ Like the other Jesuits discussed, Weitenauer

79 On Franz Neumayr, cf. P.Th. van der Veldt S.J., Franz Neumayr sJ (1697-1765): Leben und Werk eines spätbarocken geistlichen Autors (Amsterdam-Maarssen: APA-Holland University Press, 1992); Hans Gumbel, Franz Neumayr: Ein Beitrag zur Geschichte des lateinischen Dramas im 18. Jahrhundert (Frankfurt: Rheinische Verlagsanstalt und Buchdruckerei, 1938); Valentin, 'La diffusion de Corneille en Allemagne au Xviıre siècle', p. 184; Wiegand, 'Späte Jesuitenpoetik'.

$80 \quad$ Van der Veldt, Franz Neumayr sJ, p. 84.

81 Ibid., pp. 86-87; Valentin, 'La diffusion de Corneille en Allemagne au XVııre siècle', pp. 184190.

82 Neumayr, Idea poeseos, 'Praefatio', p. 2.

83 Van der Veldt, Franz Neumayr sJ, p. 86; Volker Janning, Der Chor im neulateinischen Drama: Formen und Funktionen (Münster: Rhema, 2005), pp. 70-72.

84 On the life of Weitenauer, cf. Edith Kellner, Ignaz Weitenauers Ars Poetica und Tragoediae Autumnales (unpublished doctoral thesis, University of Innsbruck, 1958), pp. 1-4; JeanMarie Valentin, Répertoire chronologique Le théâtre des Jésuites dans les pays de langue 
attributed great importance to the structural aspect of a play: the three unities, which in his view should be observed religiously. ${ }^{85}$ Corneille, Racine and Molière, are very important in Weitenauer's poetics. Corneille, unsurprisingly, is the most important of the three, as he emphasizes repeatedly. ${ }^{86}$ Racine also features prominently in Weitenauer's poetics, although he is criticized for the representation of intempestivos amores and the Aristotelian rule that the heroes should not be excessively burdened. ${ }^{87}$ Overall however, his concept of theater is more similar to Racine's practice, which a rather strict interpretation of the structural rules, than Corneille's. For comedy, he recommends Molière, who is praised for his lifelike representations of real people. ${ }^{88}$ Apart from these three famous authors, Weitenauer repeatedly praises Voltaire, but only in cases where Voltaire follows the rules.

The connection between politics and aesthetics, which I tried to illuminate in 18th century classicist Jesuit theater, to a certain extent applies to Jesuit theater and politics in other places and at other times too. Decisions about the esthetics of Jesuit theater were always taken with the political situation of the time in mind. To mention but one other example, Joseph Simons (alias Emmanuel Lobb, 1594-1671), similarly to Andreas Friz, enjoyed a position closely connected to the court, in his case the English Stuart court. ${ }^{89} \mathrm{He}$ is even said to have been instrumental in the conversion of the future James II

allemande: Répertoire chronologique des pièces représentées et des documents conservés (1555-1773), vol. 1: Première partie 1555-1728; vol. 2: Deuxième partie 1729-1773 (Stuttgart: Anton Hiersemann Verlag, 1983-1984) Hiersemanns Bibliographische Handbücher, III, 1 et 2, vol. 2, p. 1128 .

85 Weitenauer, Q. Horatii Flacci Ars Poetica, ad omne genus eloquentiae, ligatae, solutae, etiam sacrae, accommodata, et exemplis plurimis illustrata (Augsburg-Freiburg i.Br.: Wagner, 1757), pp. 25-27.

86 Weitenauer, Ars Poetica, pp. 25, 80, 104. Cf. Kellner, Ignaz Weitenauers Ars Poetica und Tragoediae Autumnales, pp. 108-109.

87 Weitenauer, Ars Poetica, p. 159; Kellner, Ignaz Weitenauers Ars Poetica und Tragoediae Autumnales, pp. 109-110.

88 Weitenauer, Ars Poetica, p. 161: 'Qui docte ac vere imitari voluerit, eum respicere iubet homines ipsos, eorumque cogitandi, loquendi, agendi modum in rem suam convertere. Sic veras voces et poeta, et orator depromet. Sic theatrum comicum Joannes Baptista Molierius implevit characteribus personarum eorumque copia et novitate Graecos Romanosque post se reliquit. Solitus enim erat, ubicunque esset, tacitus ac paene morosus dicta hominum et mores veluti ex insidiis observare et apud se expendere. Inde vero, quae idonea sibi decerpserat, in opportunitatem proximam conferebat.'

89 Alison Shell, 'Autodidacticism in English Jesuit Drama: The Writings and Career of Joseph Simons', Medieval and Renaissance Drama in England 3 (2000), 34-56. 
to Catholicism in the late 1670 s and early $1680 \mathrm{os} .{ }^{90}$ His writings as playwright, even though produced at an earlier stage of his career, should be considered in this context too. ${ }^{91}$ The resemblance of Theoctistus's court constancy in his Theoctistus to Simons's own is no coincidence.

\section{Conclusions}

In the reception of French classicist poetics discussed in this chapter, aesthetics meets politics in educational reform policy. The complicated attitude towards France in eighteenth century German-speaking areas has been described by two extremes: gallophobia and gallophilia. On the one hand, France had a bad reputation among many Germans. Its cuisine, literature and arrogant attitude towards neighboring countries were frequently criticized by German bourgeois intelligentsia. On the other, France's dominant position in Europe at the time and its cultural blossoming, surrounding the court of Louis XIV, made an enormous impact on the rest of Europe in many respects. To name a few, education, art, architecture and literature saw a lasting French influence in most areas of Europe.

The ambivalent attitude of Germans towards France can be illustrated by the writings of Johann Christoph and Luise Adelgunde Gottsched, which should be seen in the context of Enlightenment ideas developing in the Protestant German-speaking areas. Although a clear gallophobe tendency can be identified in their works, the couple primarily used French models in their attempts of creating a new German vernacular literature. They felt that French classicist theater and literature was superior to the existing vernacular literature in the German-speaking areas and aimed to create their own 'national' literature, following French models.

The Catholic German-speaking countries were influenced by the Enlightenment differently from the Protestant areas, but also here French classicism came into play. In the case of Austria, Jesuit attempts to reform the order's school theater, using the same French classicist models as Gottsched, can be directly linked to Maria Theresa's reform absolutism. The aim of her educational reforms was to create citizens who supported the common good, citizens who served the state. Spectacular baroque school theater, which took an important place in the Jesuit school curriculum at the time, in her view took away

$90 \quad$ Ibid., p. 46.

91 Ibid., p. 47. 
valuable time from more useful activities, such as learning French, German, geography and history. The performance of Latin plays and participation in spectacles with a great deal of musical entertainment and dance was not considered beneficial to the state. The emphasis on structural rules and utility, which was an important aspect of a new type of Jesuit theater, promoted by prominent Jesuits such as Andreas Friz, who was closely connected to Maria Theresa's court, fitted much better in her reform program. This theater imitated French classicism and is associated with the reception of Corneille and Racine by Gottsched in the Protestant Aufklärung. Undoubtedly, similar political and intellectual developments should be considered as important factors in Neumayr's and Weitenauer's application of the same classicist precepts.

Naturally, one can only speculate in how far this adaptation to theater poetics was applied in practice. Probably, the reality of school theater was not as dry and serious as the type of theater for which Andreas Friz argued. Even though some editions of his plays have survived, these give us revised versions, intended for a reading audience, which may not contain all the elements, such as musical interludes or ballet intermezzi, that were present in the actual performance of the play. Franz Neumayr refers to the reality of theater, when he explicitly allowed certain baroque aspects, such as choral interludes, to be used in combination with the rules of French classicism, in order to satisfy the audience's taste for spectacle. ${ }^{92}$

\section{Further Reading}

Blaschke, Bernd, 'Anleihen und Verachtung: Luise Gottscheds französischer Komödienimport als Arbeit an einem deutschen Theater', in Roman Luckscheiter and Marcel Krings (eds.), Deutsch-französische Literaturbeziehungen (Würzburg: Konigshausen and Neumann, 2007), pp. 71-85.

Brandes, Helga, 'Johann Christoph \& Luise Adelgunde Victorie Gottsched und der deutsch-französische Aufklärungsdiskurs', in Jens Stüben (ed.), Ostpreußen-Westpreußen-Danzig: Eine historische Literaturlandschaft (Munich: R. Oldenbourg, 2007) Schriften des Bundesinstituts für Kultur und Geschichte des Deutschen im östlichen Europa, 30, pp. 237-258.

Buchenau, Stefanie, The Founding of Aesthetics in the German Enlightenment: The Art of Invention and the Invention of Art (Cambridge: Cambridge University Press, 2013).

92 Van der Veldt, Franz Neumayr SJ, p. 86; Janning, Der Chor im neulateinischen Drama, pp. $70-72$. 
Grimberg, Michel, La réception de la comédie française dans les pays de langue allemande (1694-1799), vue à travers les traductions et leurs préfaces (Bern etc.: Peter Lang, 1995).

Häseler, Jens, and Albert Meier (eds.). Gallophobie im 18. Jahrhundert (Berlin: Berliner Wissenschaftsverlag, 2005).

Kapitza, Peter K., Ein bürgerlicher Krieg in der gelehrten Welt:Zur Geschichte der Querelle des Anciens et des Modernes in Deutschland (Munich: Wilhelm Fink, 1981).

Krauss, Werner, Studien zur deutschen und französischen Aufklärung (Berlin: Rütten and Loening, 1963).

Julliard, Catherine, Gottsched et l'esthétique théâtrale française: La réception allemande des théories françaises (Bern etc.: Peter Lang, 1998).

Meier, Albert, 'Plus ultra! Johann Christoph Gottscheds gallophobe Gallophilie', in Raymond Heitz, York-Gothart Mix, Jean Mondot and Nina Birkner (eds.), Gallophilie und Gallophobie in der Literatur und den Medien in Deutschland und in Italien im 18. Jahrhundert (Heidelberg: Universitätsverlag Winter, 2011), pp. 195-207.

Meyer, Reinhardt, 'Das französische Theater in Deutschland', in Matthias J. Pernerstorfer (ed.), Schriften zur Theater- und Kulturgeschichte des 18. Jahrhunderts (Vienna: Hollitzer, 2012), pp. 43-66 [first published in Gerhard Sauder and Jochen Schlobach (eds.), Aufklärungen: Frankreich und Deutschland im 18. Jahrhundert (Heidelberg: Carl Winter Universitätsverlag, 1985), pp. 145-165].

Schulz, Georg-Michael, Tugend, Gewalt und Tod: Das Trauerspiel der Aufklärung und die Dramaturgie des Pathetischen und des Erhabenen (Tübingen: Niemeyer, 1988), Theatron, vol. 1. 